\title{
Historic Preservation and Planar Protection of Historic Seats in Olomouc Region
}

\author{
RUDOLF Vlastimil ${ }^{1, a^{*}}$, PEŘINKOVÁ Martina ${ }^{2, b}$ \\ ${ }^{1,2}$ Faculty of Civil Engineering, VSB - Technical University of Ostrava, L. Podéště 1875, 70833 \\ Ostrava-Poruba, Czech Republic \\ avlastimil.rudolf@vsb.cz, ${ }^{b}$ martina.perinkova@vsb.cz
}

Keywords: Historic seats, historic core, renewal, protection, historic preservation, historic reserve, heritage zone.

\begin{abstract}
The contribution is dealing with the historical reservations and zones, their declarations in historical seats of Olomouc Region and established conditions for their protection. The aim of this article is to describe the development of the planar historic protection in the historical seats of the mentioned region as well as the common and the diverse features for the protection and their practical performance.
\end{abstract}

\section{Urban Engineering and Heritage Preservation}

The City Engineering applies a multidisciplinary approach to the historical settlements in the Czech Republic [1]. In this regards it is also meeting closely the heritage preservation Both disciplines, despite their diversity and procedures must cooperate to achieve the objective, which should be the preservation of historic cores of urban settlements or their enrichment. This procedure provides great opportunities for the development of historic cities in the Czech Republic. To preserve them, but also to fix certain limits for their further development, there are applied different levels of heritage preservation.

\section{Urban Heritage Areas and their Protection Zones [2]}

The declaration of the historic centre of the city of Olomouc to become a heritage area was pronounced in 1971 and later it was modified in 1987. The declaration of the heritage centre of this city must have been no surprise, because in this case, a number of symptoms like a large area of the historical centre, antiquity, many cultural monuments, historical significance of the city, a combination of secular and spiritual authorities in the past (princely mansion, fortified town, the seat of government and church administration), etc. is co-existing $\mathrm{f}$ tin one place. The declaration was later continued by defining a protection zone of the heritage area and registering of selected cultural monuments on the UNESCO list. The establishment of the protection zones reservation has been problematic since the start, because it lacked determination of the conditions applied on heritage areas. Already in August 1987 an attempt was made to correct the dysfunctional situation when the District National Committee in Olomouc was asked to eliminate the occurred error and to correct and complete the decision. To remedy this, however, has never taken place and the consequences of failure conditions negatively impact (especially, when dealing with new construction) until today.

Lipník nad Bečvou historic centre was pronounced the heritage area as one of the last one in the Czech Republic. The fact, that it happened relatively late, does not mean there is reduction of historic and architectural qualities of the city, as because at the same time Plzen and Brno was pronounced then later on there were Kolín and Prríbor. Lipník has been on the list of cities proposed to be declared since the mid-seventies of the $20^{\text {th }}$ century, but, probably originally it was intended only for protection through heritage zone, the preserved graphical plotting range of the future heritage dates from 1985 [3]. 
To ensure the new heritage areas (and similarly for the other cities mentioned) there was an obligation determined: " When procuring the planning documentation, the importance of functional and spatial structure of the city must be strengthened and the scenic value must be protected, while the historical floor plan and corresponding urban structure should be respected in the heritage area and the corresponding urban structure..." As extremely prudent, better visionary appears the condition that: "In the heritage area, the buildings, urban spaces and areas can only be used in accordance with their capacity possibilities and their historical value of the reservation." Other conditions related to the design works and implementation of projects emphasised on: "The respect to the heritage value of the heritage area, individual premises and their dependences and urban areas and surfaces. "As an important requirement appears to be that: "When a new construction in the heritage area, the architectural relationship to the cultural monuments and their premises must be taken into an account, it is necessary to continue in building in the view of their volume and surface composition and environment and to accomplish their units by the adequate means of contemporary architecture."

Four years later in The District Office in Přerov, the Department of Culture, published "In order to protect the heritage area, in agreement with the Department of Construction and Land Use Plan of the Municipality of Lipnik nad Bečvou, the decision to determine the protective zone of City heritage area in Lipnik nad Bečvou." The conditions of the pre-set protection have generally been appropriate to the objectives for which they were claimed the height of new buildings and the mass breakdown should have been build on the scale height of the existing buildings in urban heritage area and surrounding buildings in the protection zone; also, the significant visual axes and vistas of the historic centres should have been respected and preserved. Also the existing street network should have been taken into an account. The instruction of the reasons for defining a protection zone is also rather understandable. "The establishment of a protection zone Lipnik means an increased monitoring of the protection of the historic core from the adverse effects of an intervention especially in construction activities in the established protection zone." The protection zones were more formally defined, nevertheless, in practice there is no application of the decision because allegedly in this case the negotiated definition was not in compliance with the applicable legal framework, and therefore is invalid [4].

It may seem that the chances of showed that there are still some reserves, as we can be convinced by the prepared declaration of Luhačovice to become a heritage area. On the other hand, there are also sad cases where the heritage protection was reduced or completely eliminated, examples is the city Horní Slavkov ort he city Planá (near Mariánské Lázně).

In the area of Olomouc region is not space for pronouncing a new urban heritage areas and therefore we must protect historic city very good on this present day. The cities such as Horní Slavkov and Planá are sufficient warnings.

\section{City Heritage Areas and the Protections Zones}

The proposal to declare the historic core of the city Prostějov as a heritage area was drawn by the Brno department of the State Institute of Monument Preservation and the Protection of Nature (SÚPPOP). The graphic supplement dates on December 1984. Since Prostějov at that time belonged to the South Moravian Region, the declaration a heritage area in Prostějov was declared by a decree of the Regional National Committee, unlike other areas in the later declarations, when it was ordained the Government of the Czech Republic, as well as due to changes in the way declaration. For Prostějov, there were preparations to be declared a heritage area and concurrently, the indication of its protection zone was being prepared, as we can learn from the letter as of December 28, 1989. The intended protection zone should have been rather extensive. That was probably one of the most essential reasons why the announcement of the zone has never come true. The intended size, however, could be justified. The protection zone was supposed to involve largely relatively intact streets and squares with quality architecture, dating from the last quarter of the nineteenth century until the first half of the twentieth century. Some buildings would certainly withstand the strict standards imposed on the cultural heritage, but the declaration was not 
pronounced for various reasons. In 1990, the debate about the declaration of the protection zone continued in which the Chief Architect of the District National Committee (later the District Office) actively took part in, who pushed through removing of Rejskova street from the protection zone and its direct integration into the heritage zone, as Rejskova street is one of the most representative parts of the city. To promote such legitimate requirement was still possible, because the heritage area was declared on November 20, 1990. Though, that did not happen. On the contrary to the positive input, however, the department of the Chief Architect disagreed with the condition to maintain the hight of the buildings of the protection zone, arguing that the low building area is supposedly worthless. The resulting contradiction is rather crucial as it reveals two different perspectives on an urban planning of the city. A representative of the region sees the room for the new, higher constructions and the existing low-floor is understood as something obsolete, provincial and even rural, perhaps as a potential area for possible investments. Therefore, the heritage care started to be afraid of the loss of the real face of the character of the city, the removal of its peculiarities and depreciation of close and faraway views. The newly submitted decision to declare a protection zone bears the date November 20, 1990, which evokes the idea of kind of coordination between the announcement of the heritage area and protection zone, but the protection zone was not declared at the end, thereby the best opportunity to strengthen the extensive conservation of historic parts of the city and prevent the realization of disruptive interventions in the immediate vicinity of the historic city centre was wasted. The negotiations of the concerned parties then continued throughout the entire first half of the nineties. Out of the conditions that were supposed to be applied within the protection zone we can highlight the essential ones from the perspective of the heritage care: "Preserving and cherishing the character of individual buildings in urban and originally suburban parts, keeping urban planning scheme of regulation of the 20th - 30th years of the 20th century (shapes of the squares, a regular grid, etc.), prioritizing when dealing with traffic routes maintaining the individual residential blocks and other buildings." Over time, eventually, the effort to define a protection zone of urban heritage conservation area in Prostějov just trailed off. At the turn of the millennium, the department of the State Institute of Monument Preservation in Brno processed the so called "Revision of heritage preservation zone boundaries in Prostějov" that would include the most valuable parts from the urban and architectural point of view from the project of the protection zone. However, even this option of the range of the planar protection was not approved [6].

The urban heritage areas in the Olomouc Region were declared by the decree of the Ministry of Culture of the Czech Republic. Namely, there were the heritage areas in Branná, Hranice, Litovel, Mohelnice, Přerov Šternberk, Štíty, Šumperk, Tovačov, Uničov and Zlaté Hory. Then, in 2003 there was declared another heritage area in the city Potštát [5]

As well as for Prostějov, the protection zones of the heritage areas were prepared for other cities like Šumperk, Mohelnice, Přerov, Branná a Tovačov. In Branná, the protection zone does exist; nevertheless the protection is not taken into an account in practice. In Přerov, the protection area is a functional part of the planar heritage protection area of the city. The protection zone appropriately follows the heritage area, in size it is not excessive, if necessary though, it exceeds the River Bečva, it contains even the monuments of villa housing, and also it protects the environment, which could be rather difficult under certain circumstances to defense from the heritage preservation point of view.

On July 2, 1993 the Department of Culture of Šumperk District Office annulled their former decision to declare a preservation zone of the heritage area in its entirety for the alleged legal defects.

In Tovačov, the protection zone of the heritage area was defined in 1995. The decision on the establishment of the protection zone contains among the border classification also the identification of the standard conditions, which must be kept within the boundaries.

\section{City Heritage Areas and the Protection Zones}

The determination of the conditions for the planar protection through the heritage reservations (in our case it is Lipník nad Bečvou) and the protection zones is not fundamentally 
indistinguishable. In all cases of the declaration - the statement or the definition (i.e, where the conditions of the protection were set), the emphasis is put on keeping the height of new buildings and its mass division so that it followed the vertical scale of the existing buildings, on the use of individual premises and areas according to their capacity and technical conditions and in accordance with their historical value of the reserves and zones; next to the respect of the outstanding visual axes and vistas of the historic centres, respecting the existing street network, squares and structures (square shapes, regular grid), etc. All such conditions are aimed at one goal - to preserve the character of our historic houses and to prevent the damage or destruction of their elements and the entire structure. The conditions are not infeasible and a proper state and municipal administration and good designers, as well as the planners can seamlessly work with them for the benefit of residents of historic settlements and their visitors.

\section{Summary}

The paper aimed to bring the issue of the preparation and supporting the idea of the planar protection of chosen cities in the Olomouc Region and conditions of such protection.

The planar protection of the historic mansions in the monitored region was not a cakewalk. Behind the preparation of the proposals for the protection of each individual sites we can find a large amount of work of people who participated in the researches of the cores of the cities and building-historical surveys of individual buildings, contractors of maps and graphic materials, persons preparing regulations, decisions or orders. Despite these efforts sometimes, for various reasons, the whole demanding task vanished, and it did not end in a successful evaluation, which subsequently have enabled the transformation of towns with significant adverse effects for the city. Despite these potential failures, the whole work expended in a huge benefit for a thorough understanding of urbanism of the most valuable historic mansions of the Olomouc region and for the efforts to maintain its character and uniqueness.

\section{References}

[1] P. Štyr a kol. Městské inženýrství I., Academia, Praha, 1998, též Kolektiv autorů. Městské inženýrství, stavební kniha 2011, ČKAIT, Praha, 2011.

[2] Zákon č. 20/ 1987 Sb., o státní památkové péči.

[3] Nařízení vlády ČSR č. 54/1989 Sb., o prohlášení území historických jader měst Kolína, Plzně, Lipníku nad Bečvou a Př́bora za památkové rezervace, and K. Kibic, A. Vošahlík. Památková ochrana a regenerace historických měst v České Republice 1945-2010, Národní památkový ústav, Praha, 2011, p. 156.

[4] Rozhodnutí o určení ochranného pásma. All the documents (leters etc) used in this article are stored in accessible archive of department EDI NPÚ in Olomouc and are without signatures.

[5] Vyhláška MK ČR č. 476/1992, ze dne 10.9.1992, o prohlášení území historických jader vybraných měst za památkové zóny and Vyhláška MK ČR č. 108/2003, ze dne 1. dubna 2003, o prohlášení území s historickým prostředím ve vybraných městech a obcích za památkové zóny a určování podmínek pro jejich ochranu.

[6] The literature concerning the architecture of Prostějov, for example M. Chytil, M., O. Belšík, T. Cydlík, M. Kvapilová, D. Roháčková, V. Rudolf. Slavné stavby Prostějova, FOIBOS, Praha, 2009, V. Rudolf. Př́běh jednoho obchodně-výrobního areálu v Prostějově (Svatoplukova ul. č. pop. 2455), in. M. Peřinková, ad. Současné formy uživání industriálních historických objektů. Gintel Allan - Gasset Praha, 2012 etc. 